\title{
PERANCANGAN PERANGKAT PEMBELAJARAN DRAMA RADIO/ TELEVISI BERBASIS CERITA RAKYAT SULAWESI SELATAN
}

\author{
Prusdianto, Hamrin, Faisal \\ Pendidikan Seni Drama Tari dan Musik, Fakultas Seni dan Desain, Universitas Negeri Makassar \\ prusdianto@unm.ac.id \\ hamrnsamad@gmail.com \\ faisal@gmail.com
}

\begin{abstract}
Practical education cannot be separated from culture. Folklore is the hallmark of every region that has a diverse cultural culture including the richness of the culture and history of each region. Folk stories that are still abundant in the community will become extinct if they are not immediately examined and recorded. Documentation of folktales is increasingly important and urgent to do immediately. One alternative documentation is through radio drama media.

The purpose of this study is to; knowing how to develop a preservation-based learning tool for South Sulawesi folklore with a 4-D model, knowing the validity, practicality, effectiveness of preservation-based learning tools of South Sulawesi folklore in the Drama Radio / Television course radio drama script writing material developed.

This type of research is a type of research and development. The products produced from this study are learning devices consisting of Semester Learning Plans (RPS), Student Task Plans (RTM) based on the preservation of South Sulawesi folklore. Analysis of the data obtained in this study are grouped into 3 namely validity analysis, practicality and effectiveness. Learning using media accompanied by RTM is carried out in accordance with the RPS and examined based on the assessment instruments that have been prepared. After the implementation of the learning device carried out.
\end{abstract}

Keywords: Radio Drama, Folk Story, South Sulawesi

\begin{abstract}
Abstrak
Pendidikan secara praktis tidak dapat dipisahkan dengan kebudayaan. Cerita rakyat menjadi ciri khas setiap daerah yang mempunyai kultur budaya yang beraneka ragam mencakup kekayaan budaya dan sejarah yang dimiliki masing-masing daerah. Cerita rakyat yang masih banyak terdapat di masyarakat akan punah jika tidak segera diteliti dan dibukukan. Pendokumentasian cerita-cerita rakyat itu semakin penting dan mendesak untuk segera dilakukan. Salah satu alternatif pendokumentasiannya adalah melalui media drama radio.

Tujuan dari penelitian ini adalah untuk; mengetahui cara mengembangkan perangkat pembelajaran berbasis pelestarian cerita rakyat Sulawesi Selatan dengan model 4-D, mengetahui validitas, praktisan, efektivitas perangkat pembelajaran berbasis pelestarian cerita rakyat Sulawesi Selatan pada mata kuliah Drama Radio/ Televisi materi penulisan naskah drama radio yang dikembangkan.

Jenis penelitian ini merupakan jenis penelitian dan pengembangan (Research and Developmen). Produk yang dihasilkan dari penelitian ini berupa perangkat pembelajaran yang terdiri dari Rencana Pembelajaran Semester (RPS), Rencana Tugas Mahasiswa (RTM) yang berbasis pelestarian cerita rakyat Sulawesi Selatan. Analisis data yang diperoleh dalam penelitian ini dikelompokkan menjadi 3 yaitu analisis kevalidan, kepraktisan dan keefektifan. Pembelajaran menggunaka media disertai dengan RTM dilaksanakan sesuai dengan RPS dan diperiksa berdasarkan instrumen penilaian yang telah disusun. Setelah implementasi perangkat pembelajaran yang dilakukan.
\end{abstract}

Kata kunci: Drama Radio, Cerita Rakyat 


\section{PENDAHULUAN}

Pendidikan tinggi merupakan jenjang pendidikan setelah pendidikan menengah salah satunya berfungsi untuk mengembangkan kemampuan dan membentuk watak serta peradaban bangsa yang bermartabat dalam rangka mencerdaskan kehidupan bangsa (Undang-undang nomor 2 tahun 2012). Konsep mencerdasakan kehidupan bangsa tidak hanya sampai kepada tujuan kecerdasan otak, melainkan lebih dari itu. Kecerdasan yang dimaksudkan adalah kecerdasan pikir, hati, rasa dan raga.

Pendidikan secara praktis tidak dapat dipisahkan dengan kebudayaan. Menjaga dan melestarikan kebudayaan sendiri, secara prosesnya yang paling efektif adalah dengan cara pendidikan. Sebab tujuan lain dari pendidikan adalah melestarikan dan selalu meningkatkan kebudayaan itu sendiri. Adanya pendidikan pada akhirnya menjadikan kebudayaan akan terus beregenerasi dari waktu ke waktu berikutnya.

Pendidikan sekaligus adalah sebuah subsistem bagi kebudayaan dan sistem tersendiri yang berada di luarnya, yang menunjang pembentukan, pengembangan, dan pelestarian kebudayaan. Sebagai sebuah subsistem, pendidikan adalah bagian terpenting dari kebudayaan, berfungsi sebagai pengarah kebudayaan dan sekaligus mekanisme pewarisan nilai-nilai budaya sesuatu masyarakat dari satu ke lain generasi.

Mata kuliah Drama Radio/ Televisi adalah mata kuliah yang berisi penguasaan pembelajaran dan pengenalan teknik perekaman dengan menggunakan aplikasi untuk membuat drama radio, editing suara, penambangan musik ilustrasi, musik efek, musik suasana dan penyelesaian karya drama radio, pengenalan kamera, bahasa gambar, angle, type shoot, lighting, editing dan artistik dan aplikasi editing. Selain itu, praktik bermain individual dan kelompok pembuatan drama radio baik iklan ataupun drama cerita dan pembuatan drama televisi baik iklan, video klip, film pendek, ataupun film panjang.

Mata kuliah ini menjadikan radio maupun televisi sebagai media, alat atau sarana yang digunakan untuk menyampaikan pesan. Alur dari penyampaian pesan ini awalnya berupa ide, selanjutnya ide yang dimiliki oleh mahasiswa dituangkan dalam sebuah cerita. Cerita nantinya ini akan melalui proses yang pada akhirnya menjadi karya akhir berupa drama dalam media radio dan televisi.

Kelebihan drama dengan media radio maupun televisi jika dibandingkan dengan pertunjukan teater konvensional yang bersifat ephemeral, bahwa radio dan televisi sudah terformat dalam file audio maupun video sehingga bisa kapan saja dan dimana saja bisa didengar ataupun dilihat. Hal ini pulahlah yang menjadikan media radio maupun televisi selain digunakan sebagai media ekspresi seni juga sebagai media dalam pelestaraian kebudayaan khususnya cerita-cerita rakyat tradisional.

Cerita rakyat merupakan cerita yang berasal dari masyarakat dan berkembang dalam masyarakat secara turun menurun dan disampaikan secara lisan. Cerita rakyat menjadi ciri khas setiap daerah yang mempunyai kultur budaya yang beraneka ragam mencakup kekayaan budaya dan sejarah yang dimiliki masing-masing daerah. Cerita rakyat adalah suatu kebudayaan yang tumbuh dan berkembang di tengah-tengah masyarakat yang diwariskan secara lisan sebagai milik bersama. Cerita rakyat tidak hanya berfungsi sebagai alat hiburan, melainkan dapat menjadi sarana pendidikan (Tasliyatun, 2015: 1).

Pada studi pendahuluan menunjukan dalam perkuliahan drama radio/ televisi di program Studi pendidikan Seni Drama, Tari dan Musik, Fakultas Seni dan Desain, Universitas Negeri Makassar, kebanyakan mahasiswa memproduksi karya akhir berupa cerita-cerita yang berkenaan dengan cerita atau peristiwa keseharian dengan setting latar budaya modern. Tidak ada satupun mahasiswa yang mengangkat ide cerita berdasarkan cerita rakyat tradisional. Padahal cerita rakyat dalam muatan dramatika apalagi moral tidak kalah dengan cerita atau peristiwa modern.

Cerita rakyat mengisahkan suatu kejadian di suatu tempat atau asal muasal suatu tempat. Tokoh-tokoh yang dimunculkan dalam cerita rakyat dijadikan sebagai pembelajaran moral dalam kehidupan seharihari. Selain itu, pembelajaran moral dapat diambil dari amanat cerita rakyat tersebut. Jaman dahulu ketika budaya masih kental, cerita rakyat menjadi suatu sarana untuk mendidik anak dalam memberikan contoh perilaku yang baik (Tasliyatun, 2015:2). 
Cerita rakyat yang masih banyak terdapat di masyarakat akan punah jika tidak segera diteliti dan dibukukan. Pendokumentasian cerita-cerita rakyat itu semakin penting dan mendesak untuk segera dilakukan. Salah satu alternatif pendokumentasiannya adalah melalui media drama radio/ televisi.

Berdasarkan pernyataan di atas, maka peneliti merancang perangkat pembelajaran berbasis pelestarian cerita rakyat Sulawesi Selatan sebagai solusi alternatif dalam melestarikan cerita dan nilai-nilai moral yang terkandung di dalam cerita rakyat tersebut. Peneliti akan meneliti dan merancang perangkat pembelajaran berbasis cerita rakyat khususnya cerita rakyat yang ada di Sulawesi Selatan.

Perancangan perangkat pembelajaran yang dimaksud peneliti adalah perancangan perangkat pembelajaran yang akan menghasilkan produk setelah diuji kevaliditasannya, kepraktisannya dan keefektifannya oleh tim validator atau ahli. Produk yang telah dinyatakan memenuhi syarat oleh tim validator itulah produk yang nantinya akan digunakan dalam proses pembelajaran.

Perancangan perangkat pembelajaran yang berbasis pelestarian cerita rakyat Sulawesi Selatan ini menggunakan model pengembangan 4-D yang dikembangkan oleh S. Thiagarajan, Dorothy S. Semmel, dan Melvyn I. Semmel (1974) yang terdiri atas 4 tahap yaitu pendefenisian (Define), Perancangan (Design), Pengembangan (Develop), dan Penyebaran (Disseminate).

Penelitian dan perancangan ini diharapkan dapat menghasilkan produk akhir sebuah perangkat pembelajaran yang berbasis pelestarian cerita rakyat Sulawesi Selatan yang digunakan dalam proses pembelajaran mata kuliah drama radio/ televisi di Program Studi Pendidikan Seni Drama, Tari dan Musik, Fakultas Seni dan Desain, Universitas Negeri Makassar.

Berdasarkan ruang lingkup permasalahan tersebut maka yang menjadi rumusan masalah dalam penelitian ini sebagai berikut:

1. Bagaimana perancangan perangkat pembelajaran berbasis pelestarian cerita rakyat Sulawesi Selatan dengan model 4
- D yang terdiri atas 4 tahap yaitu (1) Define (Pendefinisian) (2) Design (Perancangan)

(Pengembangan)

(4) Disseminate

(Penyebaran)?

2. Bagaimana tingkat validitas perangkat pembelajaran berbasis pelestarian cerita rakyat Sulawesi Selatan pada mata kuliah Drama Radio/ Televisi yang dikembangkan?

3. Apakah perangkat pembelajaran berbasis pelestarian cerita rakyat Sulawesi Selatan pada mata kuliah Drama Radio/ Televisi praktis digunakan dalam proses pelaksanaan pembelajaran?

4. Bagaimanakah tingkat evektifitas perangkat pembelajaran berbasis pelestarian cerita rakyat Sulawesi Selatan pada mata kuliah Drama Radio/ Televisi yang dikembangkan?

Adapun manfaat yang diharapkan dari hasil penelitian ini, antara lain:

1. Tersedia perangkat pembelajaran yang dapat digunakan untuk melestarikan cerita rakyat Sulawesi Selatan pada mata kuliah Drama Radio/ Televisi.

2. Hasil penelitian ini diharapkan mampu menghasilkan produk perangkat pembelajaran berupa Rencana Pembelajaran Semester (RPS) dan Rencana Tugas Mahasiswa (RTM) yang telah teruji validitas, keefektifan dan kepraktisannya.

3. Hasil penelitian ini diharapkan dapat digunakan sebagai perangkat pembelajaran pada mata kuliah Drama Radio/ Televisi.

\section{METODE}

Jenis penelitian ini merupakan jenis penelitian dan pengembangan (Research and Developmen), yaitu suatu penelitian untuk merencanakan suatu produk. Produk yang dihasilkan dari penelitian ini berupa perangkat pembelajaran yang terdiri dari Rencana Pembelajaran Semester (RPS), Rencana Tugas Mahasiswa (RTM) yang berbasis pelestarian cerita rakyat Sulawesi Selatan.

Lokasi uji coba produk dilaksanakan di Program Studi Pendidikan SENDRATASIK FSD UNM. Subjek uji coba adalah Mahasiswa Program Studi Pendidikan Seni Drama, Tari 
dan Musik minat Seni Teater, semester ganjil 2018/2019 pada mata kuliah Drama Radio/Televisi.

Model pengembangan yang dapat dijadikan acuan untuk pengembangan perangkat pembelajaran ini adalah 4-D. 4 tahap yaitu pendefenisian (Define), Perancangan (Design), Pengembangan (Develop), dan Penyebaran (Disseminate).

Teknik pengumpulan data yang digunakan adalah:

1. Lembar validasi, lembar validasi yang digunakan yaitu lembar validasi instrument penelitian berupa RPS dan RTM dan angket respon mahasiswa. Informasi yang diperoleh melalui instrumen ini digunakan sebagai masukan dalam merevisi perangkat pembelajaran yang telah dikembangkan hingga menghasilkan produk akhir yang valid.

2. Angket, data uji kepraktisan diperoleh instrumen penelitian berupa angket keterlaksanaan perangkat pembelajaran, dan angket respon mahasiswa. Data uji kepraktisan diperlukan untuk mengetahui apakah produk hasil penelitian dapat diterapkan dalam kegiatan pembelajaran di kelas.

3. Tes hasil belajar, data uji keefektifan diperoleh dari instrumen penelitian berupa butir-butir tes. Data uji keefektifan digunakan untuk mengetahui apakah produk yang dihasilkan dapat memberikan hasil sesuai yag diharapkan.

Jenis instrumen yang diperlukan untuk mengukur efektifitas perangkat pembelajaran yang dikembangkan adalah angket dan tes hasil belajar mahasiswa.

Analisis data yang diperoleh dalam penelitian ini dikelompokkan menjadi 3 yaitu analisis kevalidan, kepraktisan dan keefektifan. Pembelajaran menggunaka media disertai dengan RTM dilaksanakan sesuai dengan RPS dan diperiksa berdasarkan instrumen penilaian yang telah disusun. Setelah implementasi perangkat pembelajaran yang dilakukan, teknik analisis data dari ketiga kelompok tersebut yaitu:

1. Analisis data kevalidan, kevalidan produk hasil penelitian dinilai oleh beberapa orang validator yakni validator yang ahli dalam penyusunan perangkat pembelajaran. Kegiatan yang dilakukan dalam proses analisis data kevalidan adalah sebagai berikut:

a. Melakukan rekapitulasi hasil penilaian ahli ke dalam tabel yang meliputi: aspek $(\overline{A i})$ dan nilai total $(\overline{K i})$ untuk masing-masing validator.

b. Menentukan rata-rata nilai hasil validasi dari semua validator untuk setiap kriteria dengan rumus:

$\overline{K i}=\frac{\sum_{j=1}^{n} \overline{V i j}}{n}$

Keterangan:

$\overline{K i}=$ rata-rata kriteria ke $\mathrm{i}$

$\overline{V i j}=$ nilai hasil penilaian terhadap kriteria kei oleh validator ke-j

$n$ = banyaknya kriteria

c. Menentukan rata-rata nilai untuk setiap aspek dengan rumus:

$$
\overline{A i}=\frac{\sum_{j=1}^{n} \overline{K i j}}{n}
$$

Keterangan:

$$
\begin{aligned}
\overline{A i}= & \text { rata-rata kriteria ke i } \\
\overline{K i j}= & \text { Rata-rata untuk } \\
& \text { aspek ke-i kriteria } \\
& \text { ke-j } \\
n \quad= & \text { banyaknya kriteria }
\end{aligned}
$$

d. Mencari rata-rata total $\overline{V a}$ dengan rumus:

$$
\overline{V a}=\frac{\sum_{j=1}^{n} \overline{A i}}{n}
$$

Keterangan:

$$
\begin{aligned}
\overline{V a} & =\text { rata-rata total } \\
\overline{A i} & =\text { rata-rata aspek ke } \mathrm{i} \\
n & =\text { banyaknya aspek }
\end{aligned}
$$

e. Menentukan kategori validitas setiap kriteria $\overline{K i}$ atau rata-rata aspek $\overline{K i}$ atau rata-rata total $\overline{V a}$ dengan kategori validasi yang telah ditetapkan:

Tabel 1. Kriteria Kevalidan Nilai Kriteria 


\begin{tabular}{cc}
\hline $\mathbf{3 , 5} \leq V \leq \mathbf{4}$ & Sangat valid \\
\hline $\mathbf{2 , 5} \leq V \leq \mathbf{3 , 5}$ & Valid \\
\hline $\mathbf{1 , 5} \leq V \leq \mathbf{2 , 5}$ & Cukup valid \\
\hline $\mathbf{0} \leq V \leq \mathbf{1 , 5}$ & Tidak valid \\
\hline $\begin{array}{c}\text { Keterangan : } \\
V=\end{array}$ \\
$\begin{array}{c}\text { Nilai rata-rata kevalidan } \\
\text { dari semua validator }\end{array}$
\end{tabular}

2. Analisis Data Kepraktisan, kepraktisan perangkat pembelajaran diukur berdasarkan hasil penilaian dari praktisi untuk menyatakan dapat tidaknya produk diterapkan di lapangan berdasarkan persepsi dan pengalamannya. Kegiatan yang dilakukan dalam proses analisis data kepraktisan adalah sebagai berikut:
a. Melakukan rekapitulasi hasil pengamatan pengelolaan pembelajaran.
b. Mencari rata-rata total dengan rumus:

$$
\bar{X}=\frac{\sum_{j=1}^{n} \overline{A i}}{n}
$$

Keterangan:

$$
\begin{aligned}
& \bar{X}=\text { rata-rata total } \\
& \overline{A i}=\text { nilai kriteri ke } \mathrm{i} \\
& n \quad=\text { banyaknya kriteria }
\end{aligned}
$$

c. Menentukan kategori keseluruhan kriteria dengan mencocokkan ratarata total dengan kategori yang telah ditetapkan:

\section{Tabel 2. Kategori Tingkat Kepraktisan Perangkat Pembelajaran}

Nilai Keterangan

$\mathbf{1} \leq V a \leq 2 \quad$ Sangat rendah

$\mathbf{2} \leq V a \leq \mathbf{3} \quad$ Rendah

$\mathbf{3} \leq V a \leq \mathbf{4} \quad$ Sedang

$\mathbf{4} \leq V a \leq \mathbf{5} \quad$ Tinggi

$$
V a=5 \quad \text { Sangat tinggi }
$$

Keterangan :

$$
V a=\text { Nilai rata-rata }
$$
kepraktisan

3. Analisis data keefektifan, data hasil pengamatan terhadap aktivitas mahasiswa selama kegiatan pembelajaran berlangsung. Selanjutnya dianalisis dan dideskripsikan analisis hasil pengamatan aktivitas mahasiswa. Data respon peserta didik terhadap perangkat pembelajaran meliputi respon mahasiswa terhadap media pembelajaran, sedangkan respon mahasiswa terhadap pelaksanaan pembelajaran meliputi respon mahasiswa terhadap suasana pembelajaran, cara dosen mengajar:

Tabel 3. Kategori Hasil Belajar

\begin{tabular}{cc}
\hline $\begin{array}{c}\text { Tingkat } \\
\text { Penguasaan }\end{array}$ & Kategori \\
\hline $\mathbf{8 5}-\mathbf{1 0 0}$ & Tinggi \\
\hline $\mathbf{6 5}-\mathbf{8 4}$ & Sangat tinggi \\
\hline $\mathbf{5 5}-\mathbf{6 4}$ & Sedang \\
\hline $\mathbf{3 5}-\mathbf{5 4}$ & Rendah \\
\hline $\mathbf{9}-\mathbf{3 4}$ & Sangat rendah \\
\hline
\end{tabular}

\section{HASIL DAN PEMBAHASAN 3.1. Hasil Perancangan Perangkat}

Hasil analisis data dari produk pengembangan perangkat pembelajaran berbasis pelestarian cerita rakyat Sulawesi Selatan akan dibahas pada bab ini. Sebagaimana telah dijelaskan pada bab sebelumnya bahwa tujuan penulisan pada penelitian ini adalah untuk menghasilkan suatu rancangan perangkat pembelajaran berbasis Pelestarian Cerita Rakyat Sulawesi Selatan pada mata kuliah Drama Radio/ Tv di Program Studi Pendidikan Sendratasik FSD UNM yang memenuhi kriteria valid, praktis, dan efektif yang disusun dan dikembangkan berdasarkan model pengembangan perangkat Thiagarajan, (4-D yang terdiri atas 4 tahap yaitu: Define, Design, Develop, dan Disseminate).

1. Deskripsi Hasil Tahap Pendefinisian (Define)

a. Analisis Awal - Akhir

Kecenderungan mahasiswa dalam membuat tugas ataupun karya akhir pada mata kuliah Drama Radio/ Tv adalah adanya anggapan bahwa cerita rakyat merupakan suatu hal yang lampau serta ketinggalan. Kebanyakan mahasiswa lebih memilih mengangkat cerita-cerita yang berlatar belakang kekinian. Sementara jika dilihat dari 
segi muatan pesan dan nilai-nilai moralnya, justru cerita rakyat memiliki muatan yang tidak kalah dengan cerita-cerita masa kini. Hal ini mengakibatkan tidak satupun mahasisiwa mengangkat cerita rakyat ataupun konten lokal sebagai tugas akhirnya. Padahal salah satu misi dari Fakultas Seni dan Desain adalah berperan aktif di dalam pengembangan potensi budaya daerah yang berhubungan dengan pendidikan seni, seni, dan desain.

$$
\text { Pengembangan potensi }
$$

budaya daerah seperti cerita rakyat adalah salah satu usaha untuk menjaga kearifan lokal sekaligus sebagai pembelajaran tentang muatan-muatan kebaikan dalam tradisi. Mata kuliah Drama Radio/ Tv memberikan pilihan alternatif pelestarian cerita yang inovatif. Jika cerita rakyat kebanyakan hanya didengar ataupun dibaca melalui penceritaan kisah-kisahnya, maka melalui Drama Radio/ Tv kisah-kisah tersebut seakan-akan dialami langsung.

Berdasarkan tinjauan tersebut dirancanglah sebuah pembelajaran yang memasukkan unsur cerita rakyat dalam menciptakan produk naskah drama radio. Perencanaan perangkat yang dikembangkan ini pada akhirnya akan mengarahkan mahasiswa untuk menjadikan cerita rakyat dalam hal ini cerita rakyat yang berasal dari Sulawesi Selatan sebagai ide cipta dalam membuat tugas akhirnya. Perangkat pembelajaran yang dikembangkan yaitu Rencana Pembelajaran Semester (RPS) dan Rencana Tugas Mahasiswa (RTM).

b. Analisis Mahasiswa

Analisis ini dilakukan untuk menelaah karakteristik mahasiswa yang meliputi latar belakang pengetahuan, perkembangan kognitif dan pengalaman belajar mahasiswa. Mahasiswa yang dianalisis dalam penelitian ini adalah mahasiswa Program Studi Pendidikan Sendratasik yang memprogram mata kuliah Drama
Radio/ Tv tahun ajaran 2018-2019 yang berjumlah sembilan orang. Kesembilan mahasiswa yang memprogram matakuliah tersebut secara peminatan kesemuanya memilih seni teater sesuai dengan kurikulum Program Studi Sendratasik dimana mengharuskan mahasiswa untuk memilih satu dari tiga peminatan yaitu, seni drama (teater), seni tari dan seni musik.

Perkembangan kognitif dari mahasiswa tersebut tergambarkan dari tingkatan semester mereka dimana sudah memasuki semester V. Dengan tingkatan semester tersebut mahasiswa telah melulusi mata kuliah penyutradaraan, pemeranan dan penulisan naskah lakon dimana akan memudahkan nantinya mahasiswa untuk membuat naskah drama radio.

Cerita rakyat yang dijadikan sebagai muatan ide oleh mahasiswa pada tingkat pemahaman mereka mengetahui dan dapat bercerita ulang tentang beberapa cerita rakyat yang ada di daerah mereka masing-masing. Hal ini tentunya menjadi hal yang positif dalam perancangan perangkat pembelajaran drama radio/ tv yang berbasis cerita rakyat Sulawesi Selatan.

c. Analisis Konsep

Analisis konsep bertujuan untuk mengidentifikasi, merinci, dan menyusun secara sistematis konsepkonsep utama yang berkaitan dengan materi yang akan dipelajari mahasiswa. Materi dalam perkuliahan ini adalah mata kuliah Drama Radio/ Tv dengan bobot 4 SKS. Berdasarkan kurikulum Program Studi Pendidikan Sendratasik untuk matakuliah Drama Radio/ Tv, maka diperoleh analisis sub pokok bahasan Penulisan Naskah Drama Radio, yang disajikan sebagai berikut: 


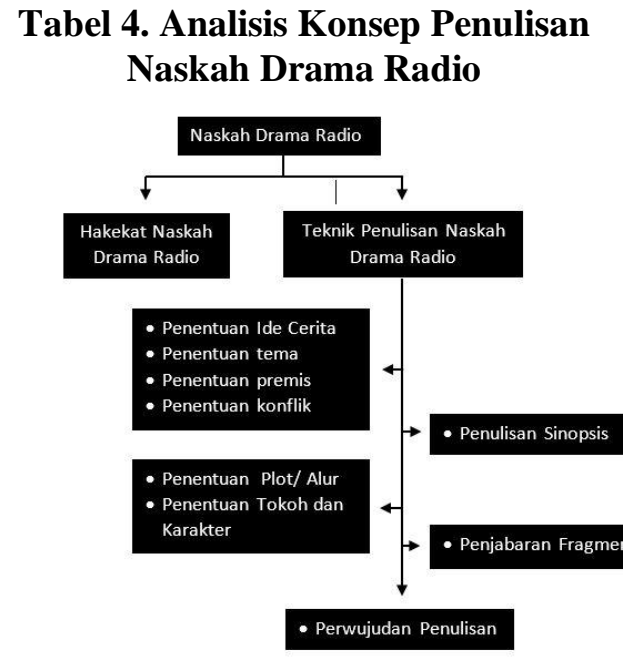

d. Analisis Tugas

Analisis tugas pembelajaran dimaksudkan untuk merumuskan tujuan-tujuan pembelajaran berdasarkan analisis konsep dan analisis tugas. Tujuan pembelajaran ini dapat tercapai dan mengacu pada materi dan pokok bahasan dan selanjutnya menjadi dasar untuk penyusunan tes dan merancang perangkat pembelajaran. Hasil analisis spesifikasi tujuan pembelajaran adalah sebagai berikut:

1) Tugas pada sub pokok bahasan hakekat naskah drama radio

a) Mejelaskan definisi naskah drama radio

b) Mengidentifikasi ciri naskah drama radio

c) Menuliskan drama radio singkat berdasarkan format penulisan naskah radio

2) Tugas pada sub pokok bahasan teknik penulisan naskah drama radio

a) Menentukan ide cerita

b) Menentukan tema

c) Menetukan premis

d) Menentukan konflik

e) Menuliskan sinopsis

f) Menentukan plot/ alur g) Menentukan tokoh dan karakter

h) Menjabarkan fragmen

3) Tugas pada sub pokok bahasan menulis naskah drama radio
a) Perwujudan penulisan bagian I
b) Perwujudan penulisan bagian II

e. Sfesifikasi Tujuan Pembelajaran

Analisis ini dilakukan untuk merumuskan hasil analisis tugas dan analisis konsep di atas menjadi indikator pencapaian hasil belajar. Indikator pencapaian hasil belajar tersebut dapat dirumuskan sebagai berikut :
1) Mahasiswa mampu mengidentifikasi ciri naskah drama radio.

2) Mahasiswa mampu mengetahui teknik penulisan naskah drama radio.
3) Mahasiswa mampu menuliskan naskah drama radio.

\section{Deskripsi Hasil Tahap Perancangan} (Design)

Pada tahap ini terdapat 4 langkah yang ditempuh yaitu penyusunan tes, pemilihan media, pemilihan format, desain awal. Adapun hasil yang diperoleh pada keempat langkah tersebut dapat diuraiakan sebagai berikut:

a. Penyusunan Tes

Dalam penyusunan perangkat tes hasil belajar terlebih dahulu dimulai dengan penyusun kisi-kisi tes. Kisikisi tes merupakan suatu acuan atau petunjuk yang harus diikuti oleh setiap penyusun tes hasil belajar. Kisi-kisi tes hasil belajar disusun berdasarkan spesifikasi tujuan pembelajaran, yang di dalamnya merupakan sebuah penyebaran butir pertanyaan yang sudah dipersiapkan sedemikian sehingga dengan butir pertanyaan tersebut dapat ditentukan dengan tepat tingkat ketercapaian penguasaan 
materi seorang mahasiswa berdasarkan spesifikasi tujuan pembelajaran, validasi oleh ahli dan uji coba lapangan. Tes hasil belajar yang dihasilkan dalam penelitian ini berupa tes kemampuan mahasiswa dalam matakuliah Drama Radio/ Tv pada materi penulisan naskah drama radio.

b. Pemilihan Media

Berdasarkan hasil analisis konsep dan perumusan tujuan pembelajaran, maka untuk mencapai evektifitas pembelajaran dilakukan identifikasi media yang diperlukan dalam proses pencapaian kompetensi. Media dalam hal ini berperan untuk memudahkan mahasiswa dalam belajar. Media yang dipilih untuk materi penulisan naskah drama radio terdiri atas slide powerpoint dan video pembelajaran. Adapun alat bantu media pembelajaran yang terdiri atas LCD, papan tulis, spidol, penghapus papan tulis, dan laptop.

c. Pemilihan Format

Pemilihan format dalam
pengembangan
pembelajaran pada sub pokok bahasan penulisan naskah drama radio meliputi pemilihan format untuk merancang isi, pemilihan strategi pembelajaran dan sumber belajar. Merancang RPs, peneliti memilih format yang disesuaikan dengan kurikulum Program Studi Pendidikan Sendratasik yang berbasis Kerangka Kualifikasi Nasional Indonesia (KKNI), meliputi identitas RPS yang terdiri atas informasi tentang matakuliah, kode, semester, sks, program studi, dosen pengampu/ penganggung jawab, capaian pembelejaran lulusan, capaian pembelajaran mata kuliah dan deskripsi mata kuliah. Setelah informasi RPS selanjutnya adalah tabel RPS sesuai dengan format berikut ini:
Tabel 5. Format RPS

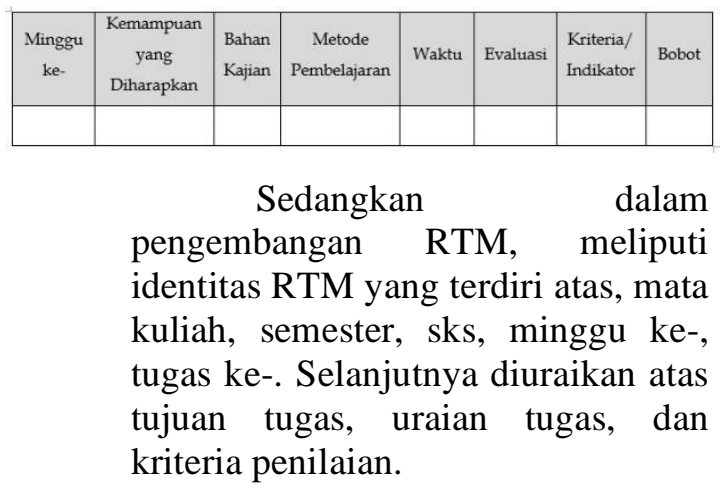

d. Desain Awal

Desain awal meliputi seluruh kegiatan yang harus dikerjakan sebelum uji coba dilakukan. Perancangan perangkat pembelajaran mengacu pada hasil analisis yang telah dilakukan pada tahap Pendefinisian, dan fase lain sebelumnya pada tahap perancangan ini. Fase ini akan menghasilkan produk berupa prototipe awal perangkat pembelajaran yang akan dikembangkan pada tahap pengembangan. Pada fase ini cerita rakyat digunakan sebagai landasan karya cipta dalam menghasilkan naskah drama radio pada perkuliahan dengan materi penulisan naskah drama radio. Adapun hasil rancangan perangkat pembelajaran pada tahap ini adalah Rancangan Pembelajaran Semester (RPS) dan Rancangan Tugas Mahasiswa (RTM). Secara umum hasil rancangan awal diuraikan sebagai berikut.

1) Rencana Pembelajaran Semester (RPS)

Rencana pelaksanaan pembelajaran terdiri dari 3 RPS dengan rincian RPS 1 untuk 1 kali pertemuan, RPS 2 untuk 2 kali pertemuan dan RPS 3 untuk 2 kali pertemuaan. Ketiga RPS tersebut diuraikan sebagai berikut:

a) RPS 1. Alokasi waktunya adalah 4 x 50 menit. Materi pada RPS 1 adalah hakekat naskah drama radio. Tujuan pembelajaran yaitu, untuk 
menjelaskan definisi naskah drama radio, untuk mengidentifikasi ciri naskah drama radio, untuk membuat naskah drama radio singkat berdasarkan ciri penulisan naskah drama radio.

b) RPS 2. Alokasi waktunya adalah $2 \times 4 \times 50$ menit. Materi pada RPS 2 adalah teknik penulisan naskah drama radio. Tujuan pembelajarannya yaitu mampu menentukan ide cerita yang bersumber dari cerita rakyat Sulawesi Selatan, menentukan tema, menetukan premis, menentukan konflik, menuliskan sinopsis, menentukan plot/ alur, menentukan tokoh, karakter dan menjabarkan fragmen.

c) RPS 3. Alokasi waktunya adalah 2 x 4 x 50 menit. Materi pada RPS 3 adalah perwujudan penulisan naskah. Tujuan pembelajarannya yaitu mampu menghasilkan naskah drama radio yang bersumber dari cerita rakyat Sulawesi Selatan.

2) Rencana Tugas Mahasiswa (RTM)

kerja peserta didik yang dikembangkan yaitu untuk sub pokok bahasan hakekat naskah drama radio, teknik penulisan naskah drama radio dan perwujudan penulisan naskah drama radio dimana karya yang dihasilkan nantinya berdasarkan cerita rakyat yang ada di Sulawesi Selatan.

3. Deskripsi Hasil Tahap Pengembangan (Develop)

Tujuan dari tahap pengembangan adalah untuk menghasilkan draft perangkat pembelajaran yang telah direvisi berdasarkan masukan para ahli, simulasi, dan data yang diperoleh dari uji coba. Kegiatan pada tahap ini adalah penilaian para ahli (validasi), simulasi dan uji coba terbatas.

a. Penilaian para Ahli

Seperti yang telah dijelaskan sebelumnya, bahwa sebelum digunakan dalam kegiatan pembelajaran hendaknya perangkat pembelajaran telah mampu mempunyai status "valid". Idealnya seorang pengembang perangkat perlu melalukan pemeriksaan ulang kepada para ahli (validator) mengenai ketepatan isi, materi pembelajaran, kesesuaian dengan tujuan pembelajaran, design fisik, dan lainlain hingga dinilai baik oleh validator. Tujuan diadakannya kegiatan validasi pada penelitian ini adalah untuk mendapatkan status valid atau sangat valid dari para ahli. Jika perangkat pembelajaran belum valid, maka validasi akan terus dilakukan hingga didapatkan perangkat pembelajaran yang valid.

Proses rangkaian validasi dilaksanakan dengan validator yaitu mereka yang berkompeten dan mengerti tentang penyusunan perangkat pembelajaran dengan materi dasar naskah drama radio sekaligus paham tentang cerita rakyat Sulawesi Selatan sehingga nantinya mampu memberi masukan atau saran untuk menyempurnakan perangkat pembelajaran yang telah disusun. Saran-saran dari validator tersebut akan dijadikan bahan untuk merevisi draft I perangkat pembelajaran sehingga menghasilkan draft II perangkat pembelajaran.

Hasil dari validasi perangkat pembelajaran adalah sebagai berikut.

1) Validasi Rencana Pembelajaran Semester (RPS)

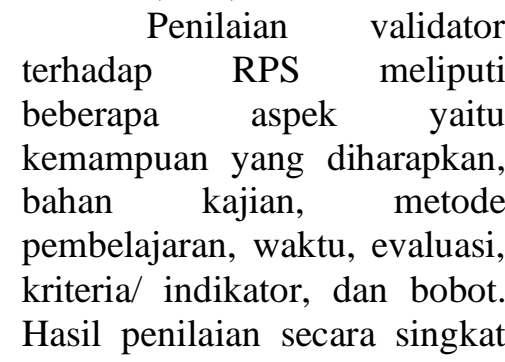


disajikan berikut ini.

\section{Tabel 6. Hasil Validasi Rencana Pembelajaran Semester}

\begin{tabular}{llc}
\hline No & \multicolumn{1}{c}{ Aspek } & Rata-rata \\
\hline 1. & $\begin{array}{l}\text { Kemampuan yang } \\
\text { diharapkan }\end{array}$ & 3,5 \\
\hline 2. & Bahan kajian & 3,6 \\
\hline 3. & Metode pembelajaran & 3,5 \\
\hline 4. & Waktu & 3,8 \\
\hline $\mathbf{5 .}$ & Evaluasi & 3,7 \\
\hline 6. & kriteria/ indikator & 3,6 \\
\hline 7. & Bobot & 4 \\
\hline & Rata-rata total & 3.67 \\
\hline
\end{tabular}

Tabel di atas menunjukkan rata-rata total dari penilaian para validator sebesar 3,67 . Hasil pencocokkan ratarata $(x)$ total dengan kategori yang ditetapkan, RPS yang dikembangkan termasuk dalam kategori valid.

2) Validasi Rencana Tugas Mahasiswa (RTM)

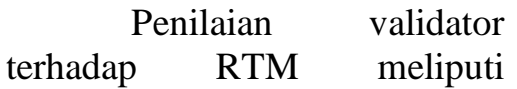
beberapa aspek yaitu tujuan tugas, uraian tugas dan kriteria penilaian. Hasil penilaian secara singkat disajikan berikut ini.

Tabel 7. Hasil Validasi Rencana Tugas Mahasiswa

\begin{tabular}{llc}
\hline No & \multicolumn{1}{c}{ Aspek } & Rata-rata \\
\hline 1. & Tujuan tugas & 3,5 \\
\hline 2. & Uraian tugas & 3,6 \\
\hline 3. & Kriteria penilaian & 3,5 \\
\hline & Rata-rata total & 3.53 \\
\hline
\end{tabular}

Tabel di atas menunjukkan rata-rata total dari penilaian para validator sebesar 3,53. Hasil pencocokkan ratarata $(x)$ total dengan kategori yang ditetapkan, RPS yang dikembangkan termasuk dalam kategori valid.

\section{3) Kepraktisan Perangkat}

Pembelajaran Berdasarkan Penilaian Validator

Lembar validasi, selain memuat tentang penilaian kevalidan perangkat pembelajaran yang diisi oleh validator, juga disertakan penilaian kepraktisan perangkat pembelajaran. Penilaian kepraktisan bertujuan untuk mengetahui apakah perangkat pembelajaran yang dikembangkan dapat dilaksanakan di lapangan berdasarkan penilaian validator, jika dipandang dari kajian pustaka dan teori-teori pendukungnya.

$\begin{array}{lr}\text { Hasil } & \begin{array}{r}\text { penilaian } \\ \text { perangkat }\end{array} \\ \text { kepraktisan } & \text { yang } \\ \text { pembelajaran } & \text { ran }\end{array}$ pembelajaran yang
dikembangkan meliputi RPS dan RTM berdasarkan penilaian validator disajikan dalam tabel berikut ini.

\section{Tabel 8. Hasil Penilaian Kepraktisan Perangkat}

\begin{tabular}{cccc}
\hline $\begin{array}{c}\text { Perangkat } \\
\text { Pembelajaran }\end{array}$ & $\begin{array}{c}\text { Valid } \\
\text { ator }\end{array}$ & Nilai & Keterangan \\
\hline RPS & 1 & B & $\begin{array}{c}\text { Dapat digunakan } \\
\text { dengan sedikit revisi }\end{array}$ \\
\cline { 2 - 4 } RTM & 1 & B & $\begin{array}{c}\text { Dapat digunakan } \\
\text { dengan sedikit revisi }\end{array}$ \\
\cline { 2 - 4 } & 2 & B & $\begin{array}{c}\text { Dapat digunakan } \\
\text { dengan sedikit revisi }\end{array}$ \\
\hline Dapat digunakan \\
dengan sedikit revisi
\end{tabular}

Berdasarkan tabel di atas dapat disimpulkan bahwa perangkat pembelajaran yang meliputi RPS dan RTM masingmasing dapat dilaksanakan di lapangan dengan sedikit revisi dan dapat dikatakan praktis.

4) Kefektifan Perangkat Pembelajaran Berdasarkan Hasil Belajar

Tes yang digunakan 
pada penelitian ini ialah uaraian sebanyak 10 nomor. Analisis tes digunakan untuk mengetahui tingkat pencapaian hasil belajar. Gambaran hasil analisis deskriptif nilai tes hasil belajar mahasiswa setelah mengikuti pembelajaran dengan menggunakan perangkat pembelajaran berbasis Cerita Rakyat Sulawesi Selatan dapat dilihat pada tabel berikut ini.

\section{Tabel 9. Statistik Nilai Setelah Pembelajaran}

\begin{tabular}{lc}
\hline \multicolumn{1}{c}{ Variabel } & Nilai \\
\hline Rata-rata & 3.67 \\
\hline Nilai Maksimun & 3.96 \\
\hline Nilai Minimun & 3.12 \\
\hline $\begin{array}{l}\text { Jumlah mahasiwa } \\
\text { yang tuntas }\end{array}$ & 9 \\
\hline $\begin{array}{l}\text { Jumlah mahasiswa } \\
\text { yang tidak tuntas }\end{array}$ & 0 \\
\hline
\end{tabular}

Berdasarkan persentase penguasaan tes hasil belajar mahasiswa, memenuhi standar ketuntasan secara klasikal dimana nilai ketuntasan mencapai $100 \%$ dan dapat dikategorikan bahwa perangkat pembelajaran yang digunakan efektif

\section{a. Simulasi}

Tahap simulasi adalah latihan awal sebelum uji coba, bertujuan untuk mengecek keterlaksanaan perangkat pembelajaran, kerja media, dan sebagainya. Pada penelitian ini, simulasi dilakukan oleh peneliti dengan subyek simulasi dua orang mahasiswa program studi Pendidikan Sendratasik FSD UNM dengan peminatan Teater. Diperadakannya simulasi menjadikan persiapan peneliti dalam melaksanakan uji coba menjadi lebih detail.

\section{b. Uji Coba Terbatas \\ Uji coba dilaksanakan dalam 3} hari, yaitu tiap hari rabu yakni tanggal 3
Oktober 2018, 10 Oktober 2018 dan 24 Oktober 2018. Hasil uji coba ini akan digunakan untuk merevisi perangkat pembelajaran (draft II) dan dihasilkan draft III perangkat pembelajaran (hasil perancangan perangkat pembelajaran). Rincian pertemuan adalah sebagai berikut.

\section{Tabel 10. Rincian Pertemuan}

\begin{tabular}{cc}
\hline Hari/ Tanggal & Rincian Pertemuan \\
\hline Rabu 3 Oktober & Pertemuan I \\
2018 & Kegiatan : pembelajaran \\
& Sub Bab Hakekat \\
& Naskah Drama Radio \\
& Alokasi Waktu 4 x 50 \\
menit \\
\hline Rabu 10 Oktober & Pertemuan II \\
2018 & Kegiatan : pembelajaran \\
& Sub Bab Teknik \\
& Penulisan Naskah \\
& Drama Radio \\
& Alokasi Waktu 4 x 50 \\
& menit \\
\hline Rabu 24 Oktober & Pertemuan III \\
2018 & Kegiatan : pembelajaran \\
& Sub Bab Perwujudan \\
& Penulisan Naskah \\
& Drama Radio \\
& Alokasi Waktu 4 x 50 \\
& menit \\
\hline
\end{tabular}

4. Deskripsi Hasil Tahap Tahap Penyebaran (Disseminate)

Perangkat pembelajaran yang dihasilkan pada akhir tahap pengembangan harus disosialisasikan dan disebarkan tetapi karena keterbatasan waktu dan materi pembelajaran yang terbatas, maka tahap penyebaran ini terbatas hanya dilakukan saat ujicoba perangkat.

\subsection{Pembahasan}

Pada bagian ini dikemukakan pembahasan hasil penelitian terhadap pengembangan perangkat pembelajaran mata kuliah Drama Radio/ Tv pada materi penulisan naskah drama radio yang meliputi dua hal, yaitu : (1) proses perancangan perangkat, dan (2) kualitas perangkat pembelajaran. Selain itu akan dibahas mengenai temuan khusus, kendala yang dihadapi selama penelitian dan keterbatasan penelitian.

1. Ketercapaian Tujuan Penelitian 
a. Proses Perancangan Perangkat Pembelajaran

Proses pengembangan perangkat pembelajaran mata kuliah Drama Radio/ Tv menggunakan model pengembangan 4-D dari $S$. Thiagarajan, Dorothy S. Semmel, dan Melvyn I. Semmel yang terdiri dari 4 tahap yaitu pendefinisian (Define), perancangan (Design), pengembangan (Develop), dan penyebaran (Disseminate). Melalui 4 tahap yang dilakukan sebelumnya pada akhirnya dirumuskan sebuah perangkat pembelajaran yang menempatkan cerita rakyat Sulawesi Selatan sebagai ide pokok penciptaan naskah drama radio. Cerita Rakyat tersebut nantinya melalui pembelajaran yang dilaksanakan pada awalnya hanyalah sebuah naskah dan pada akhirnya menjadi sebuah produk audio yaitu sebuah drama radio.

b. Kualitas Perangkat Pembelajaran

1) Kevalidan Validitas menjadi suatu
ukuran yang menunjukkan tingkat-tingkat kevalidan atau kesahihan suatu instrumen secara umum, hasil penilaian para ahli terhadap perangkat pembelajaran yang meliputi Rencana Pembelajaran Semester (RPS) dan Rencana Tugas Mahasiswa (RTM) diuraikan sebagai berikut:

a) Rencana Pembelajaran Semester (RPS), Rencana Pelaksanaan Pembelajaran yang dikembangkan pada penelitian ini memiliki ratarata total kevalidan sebesar 3,67 yang berarti RPS tersebut telah valid. RPS juga memenuhi kriteria praktis, karena kedua validator memberikan nilai "B", yang berarti RPS yang dikembangkan dapat digunakan dengan sedikit revisi. Walaupun demikian masih diperlukan perbaikan dan penyempurnaan lebih lanjut atau penyesuaian- penyesuaian jika RPS akan diterapkan pada kondisi lain.

b) Rencana Tugas Mahasiswa (RTM) yang dikembangkan pada penelitian ini memiliki rata-rata total kevalidan sebesar 3,53 yang berarti RTM tersebut telah valid. RTM juga memenuhi kriteria praktis yang berarti RTM yang dikembangkan dapat digunakan dengan revisi sedikit. Walaupun demikian masih diperlukan perbaikan dan penyempurnaan lebih lanjut atau penyesuaianpenyesuaian jika RTM akan diterapkan pada kondisi lain

2) Kepraktisan

Secara umum hasil penilaian ahli dan praktisi terhadap perangkat pembelajaran mata kuliah Drama Radio/ Tv berbasis cerita rakyat Sulawesi Selatan pada materi penulisan naskah drama radia menyatakan bahwa perangkat layak digunakan dalam pembelajaran. Sedangkan berdasarkan hasil pengamatan pada saat uji coba terhadap perangkat pembelajaran oleh dua observer menyatakan bahwa nilai keterlaksanaan perangkat pembelajaran sudah sesuai harapan.

Berdasarkan hasil
penilaian pengamatan, maka perangkat pembelajaran telah memenuhi kriteria kepraktisan. Selain itu kriteria keterlaksanaan perangkat, termasuk dalam kategori "terlaksana seluruhnya", yang berarti bahwa keseluruhan aspek yang diamati dalam pembelajaran terlaksana seluruhnya dan mahasiswa terlihat aktif dalam proses pembelajaran.

3) Keefektifan

Data hasil belajar diperoleh setelah uji coba dengan menggunakan instrument tes hasil belajar. Tes hasil belajar diberikan bertujuan untuk mengetahui 
tingkat penguasaan peserta didik terhadap materi setelah dilaksanakan proses pembelajaran dengan perangkat pembelajaran berbasis cerita rakyat Sulawesi Selatan. Berdasarkan hasil analisis tes hasil belajar bahwa dari 9 mahasiswa yang memprogram mata kuliah Drama Radio/ Tv kesemuanya memproleh nilai tuntas pada materi penulisan naskah drama radio yang merupakan perancangan perangkat pembelajaran.Dengan demikian, penguasaan tes hasil belajar peserta didik sudah memenuhi standar ketuntasan.

\section{SIMPULAN DAN SARAN 4.1. Kesimpulan}

Berdasarkan hasil penelitian dan uji coba perangkat pembelajaran Drama Radio/ Tv berbasis cerita rakyat Sulawesi Selatan materi penulisan naskah drama radio pada kelas mahasiswa Program Studi Pendidikan Sendratasik FSD UNM angkatan 2016 diperoleh beberapa kesimpulan sebagai berikut:

1. Pengembangan perangkat pembelajaran pada penelitian ini menggunakan model 4D yg terdiri dari 4 tahap yaitu pendefenisian, perancangan, pengembangan dan tahap penyebaran. Adapun langkah-langkah kegiatan yang dilakukan adalah sebagai berikut; (a) Tahap pendefenisian, meliputi kegiatan analisis awal-akhir, analisis mahasiswa, analisis konsep dan analisis tugas, (b) Tahap perancanagan, meliputi kegiatan pemilihan media, pemilihan format dan rancangan awal perangkat pembelajaran (draf/prototipe 1), (c) Tahap pengemabangan, meliputi kegiatan validasi ahli, revisi 1 (draf/prototipe 1), uji coba (draf/prototipe 2), sehingga diperoleh hasil perancangan.

2. Berdasarkan data uji coba kevalidan perangkat pembelajaran dengan beberapa revisi, dapat disimpulkan bahwa perangkat pembelajaran berupa RPS dan RTM memenuhi kategori valid.
3. Berdasarkan uji coba kepraktisan perangkat pembelajaran, dapat disimpulkan bahwa perangkat pembelajaran yang dirancang memenuhi kategori kepraktisan melihat rata-rata hasil dari pengamatan keterlaksanaan perangkat pembelajaran.

4. Berdasarkan uji coba keefektifan perangkat pembelajaran, dapat disipulkan bahwa perangkat pembelajaran berbasis keterampilan informasi pada mata kuliah Drama Radio/ Tv memenuhi kategori efektif.

\subsection{Saran}

Hasil penelitian memberikan saran/kontribusi terhadap aplikasi dan/atau pengembangan ilmu. [Times New Roman, 11, normal].

Berdasarkan hasil penelitian ini, dikemukakan beberapa saran sebagai berikut:

1. Perancangan perangkat pembelajaran yang dikembangkan dalam penelitian ini sudah memenuhi kreteria kualitas yang baik sehingga disarankan dapat diimplementasikan dalam pembelajaran di kelas untuk mata kuliah Drama Radio/ Tv.

2. Perancangan perangkat pembelajaran berbasis Pelestarian Cerita Rakyat Sulawesi Selatan hendaknya dikembangkan untuk materi lainnya yang cocok diajarkan dengan model ini, sehingga mahasiswa akan lebih termotivasi untuk melestarikan nilai-nilai luhur tradisi.

\section{DAFTAR RUJUKAN}

Astuti, Linda Dwi. 2016. Pengembangan Perangkat Pembelajaran Fisika Aktif Tipe Information Search Berbasis Kearifan Lokal DIY untuk Meningkatkan Kemampuan Berpikir Kritis dan Nilai Karakter Siswa SMA. Program Studi Pendidikan Fisika, Program Pascasarjana Universitas Negeri Yogyakarta. Tesis.

Danandjaja, James. 2007. Folklor Indonesia: Ilmu Gosip, Dongeng, dan lain-lain. Jakarta: Grafiti. 


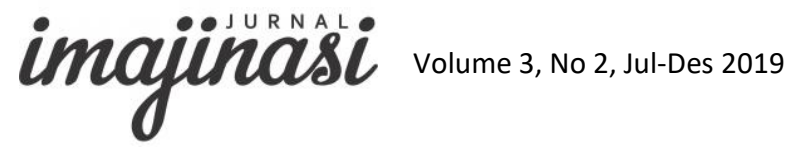

Mabruri, Anton. 2013. Manajemen Produksi Program Acara Televisi; Format Acara Drama. Jakarta: PT Grasindo.

Mawardi, Dodi. 2008. Penulisan Naskah Drama Radio https://dodimawardi.wordpress.com/2 008/05/13/penulisan-naskah-dramaradio/. diakses tanggal 9 Maret 2018.

Permendikbud No. 49 tahun 2014 tentang Standar Nasional Pendidikan Tinggi

Peraturan Presiden No 08 tahun 2012 tentang Kerangka Kualifikasi Nasional Indonesia (KKNI).

Roesdiono, Eddy. 2012. Fiksi Audio untuk Menyambung Nyawa Sandiwara Radio. Kompasiana. https://www.kompasiana.com/eddyro esdiono/fiksi-audio-untukmenyambung-nyawa-sandiwararadio_550b6de18133115e76b1e5c6. diakses tanggal 9 Maret 2018.

Sujana, I Made. 2015. Rambu-rambu Pengembangan Rencana Pembelajaran Semester (RPS). English Education Department, Faculty of Education, University of Mataram.

Sukadaryanto. 2010. Sastra Perbandingan: Teori, Metode, dan Implementasi. Semarang: Griya Jawi.

Suprihatiningrum, J. 2013. Strategi pembelajaran: Teori \& Aplikasi.

Suhadi. 2007. Petunjuk dan Pedoman Pembelajaran. Surakarta: Universitas Muhamadiyah Surakarta.

Tasliyatun, Dewi. 2015. Pelestraian Cerita Rakyat Kabupaten Semarang. Jurusan Bahasa dan Sastra Jawa, Fakultas Bahasa dan Seni, Universitas Negeri Semarang. Skripsi.

Tomlinson, B. 2003. Developing Materials for Language Teaching. London: Bloomsbury

Thiagarajan, S., Semmel, D. S \& Semmel, M. I. 1974. Instructional Development for Training Teachers of Expectional Children. Minneapolis, Minnesota: Leadership Training Institute/Special Education, University of Minnesota.
Undang-undang Nomor 8 Tahun 1992 tentang Perfilman.

Undang-undang Republik Indonesia Nomor 12 Tahun 2012 tentang Pendidikan Tinggi. 